Journal of Humanities, Social and Management Sciences (JHSMS)

eISSN: 2788-4791 (online)

https://doi.org/10.47264/idea.jhsms/2.1.3

Vol. 2, No. 1 (January-June 2021), 24-37

https://www.ideapublishers.org/index.php/jhsms

Review Article

\title{
Prolonged occupation: An analysis of obligations of the occupying powers in an occupied territory and contemporary challenges
}

\author{
Sardar M. A. Waqar Khan Arif* \\ Department of Law, University of Kotli, Azad Jammu and Kashmir, Pakistan.
}

*Correspondence Emails: sardarwaqarkhan@gmail.com

Published: August 15, 2021

\begin{abstract}
The International Law of Occupation (ILOC) regulates all kinds of occupation. However, the other bodies of law, such as, International Humanitarian Law (IHL) and International Human Rights Law (IHRL) also apply in times of occupation. These bodies of law create obligations especially on states and in particular, on the occupying powers. The presumption is that occupations are temporary in nature but why prolonged occupations? In this context, this article focuses on legal aspects of belligerent prolonged occupation. It evaluates the international legal framework and sources of belligerent prolonged occupation. While protection of civilians is central to the bulk of texts of international treaties and the occupiers have obligations, it investigates into obligations of the occupying powers in occupied territory by analysing the existing legal framework under IHL and IHRL. Further, it also discusses the provisions of ILOC. The argument developed throughout this article is that the occupying powers are under humanitarian and human rights obligations to guarantee the best possible protection of rights of occupied people in the case of prolonged occupation in particular and adding on that IHL and IHRL apply in complementarity in situations of prolonged occupation. For the purpose of this article, qualitative method is followed, and existing literature on the subject has been analysed.
\end{abstract}

Keywords: International Humanitarian Law, International Human Rights Law, belligerent occupation, prolonged occupation, occupied territory, civilian protection, obligations of occupying powers, maintenance and public order, challenges.

\section{How to Cite:}

Arif, S. M. A. W. K. (2021). Prolonged occupation: An analysis of obligations of the occupying powers in an occupied territory and contemporary challenges. Journal of Humanities, Social and Management Sciences (JHSMS), 2(1), 24-37. https://doi.org/10.47264/idea.jhsms/2.1.3

Publisher's Note: IDEA PUBLISHERS (IDEA Journals Group) stands neutral regarding jurisdictional claims in the published maps and institutional affiliations.

Copyright: ( 2021 The Author(s), published by IDEA PUBLISHERS (IDEA Journals Group) This is an Open Access article published under the Creative Commons Attribution-Non Commercial 4.0 International License (http://creativecommons.org/licenses/by-nc/4.0/) 


\section{Introduction}

Occupations are significant in number worldwide. For instance, Britain asserted its control and sovereignty over Cyprus and Egypt during World War-I by way of occupation (Bhuta, 2005). It is reflected by the US Courts. For example, in U.S. v. Rice, the Court held that: "[b]y the conquest and military occupation of [the U.S. territory of] Castine, the [British] enemy acquired that firm possession which enabled him to exercise the fullest rights of sovereignty over that place". Further, the court held that, "by the surrender the inhabitants passed under a temporary allegiance to the British government, and were bound by such laws and such only, as it chose to recognize and impose" (United States v. Rice, 1819). Before the adoption of Hague Regulations, it was considered that the occupant has free choice. For instance, Chief Justice Taney reaffirmed the view that, "by the laws and usages of nations, conquest is a valid title, while the victor maintains the exclusive possession of the conquered country" (Fleming v. Page, 1850).

Though Lieber Code contains certain provisions, but it did not cover all aspects of occupation. For instance, the issue of sovereignty of the occupier was missing in the Code (Benvenisti, 2008). Later, Hague regulations were legislated in order to address occupations. The Lieber Code provides instructions for the occupiers. For instance, it authorizes legislation by occupiers but only "as far as military necessity requires," (Leiber Code, 1863, art.3). It also requires the occupier "to be strictly guided by the principles of justice, honour, and humanity (Lieber Code, 1863, art. 4)" and to "acknowledge and protect . . . religion and morality; strictly private property; the persons of the inhabitants, especially those of women: and the sacredness of domestic relations" (Lieber Code, 1863, art. 37). Some of the provisions are included in the Hague regulations of 1899 and 1907. Later, after World War-II, the Geneva Conventions were drafted but new concepts, for example, belligerent prolonged occupation are also arising. The most important kind of occupation is prolonged occupation.

The legal consequences of prolonged nature of occupation are significant for consideration. The prolonged nature not only affects the economic stability but also creates volatile and extreme conditions, which amount to reduction of growth. The gross human rights violations in occupied areas adversely affect the life of the occupied, which must be taken into consideration by other states and international community. The evil of occupation may be removed systematically. Because of such kind of occupation, number of activities and their forms arose. These are resistance, armed resistance, violence, instability, terrorism, aggression and much more. This debate raises certain questions, such as, what is the legal position of prolonged occupation under international law? Is it legitimate or legal? What are its definition and its sources? Is there any legal framework for the occupying powers obligations during prolonged occupation? What are obligations of the occupiers under international law? What are the challenges during prolonged nature of occupation? The objective of this article is to analyse relevant laws pertaining to prolonged occupation and obligations of the occupying powers. The research methodology is qualitative and empirical.

This article aims to address all these questions. The rest of the article is proceeded as follow. Section 2 analyses the term occupation and defines it because it links to prolonged occupation. Section 3 analyses the term belligerent prolonged occupation. Section 4 discusses international legal framework and points out key instruments relating to occupation. Given the framework, section 5 identifies the sources of the prolonged occupation by analysing the relevant 
Prolonged occupation: An analysis of obligations of the occupying powers in an occupied ...

provisions of the instruments. The objective of this article is to analyse the obligations of the occupying powers by analysing the relevant provisions of international law therefore it is addressed in section 6 . Based on these obligations, section 7 points out challenges for states in relation to prolonged occupation. Sections 8 concludes the paper.

\section{The term occupation and its definition}

Under international law, the term occupation is not defined in particular. However, it acknowledges the occupation as a lawful method in armed conflict. The existence of occupation necessitates the application of various bodies of law, such as, International Law of Occupation (ILOC), International Humanitarian Law (IHL) and International Human Rights Law (IHRL). While ILOC is based on traditional law and purely concerns with occupation, IHL and IHRL also regulates and governs the occupying powers and their obligations. The former is purely designed for the situations of armed conflict whereas the later is applicable in general situations. Under the Hague Regulations of 1907, territory is occupied when it gains "effective control" of territory by use of force (Hague Regulations, 1907, art. 3).

It means that the occupying force must meet the test or criteria of effective control. When effective control takes place over a foreign territory, the bulk of ILOC comes into action. The provisions of ILOC require the occupying powers to take necessary steps for protection of people in occupied territory. The fundamental rights of the occupied people cannot be snatched away in any context by the occupying power. The occupying powers are required to protect the rights of the occupied people under its control when it stepped into its shoes, the foreign territory. The occupying powers have administrative duties and obligations to respect, protect and fulfil rights of the occupied population. The civil life and public order of the occupied people cannot be endangered or threatened in any way. Along with the obligations created by ILOC, the occupying powers are also under humanitarian and Human rights obligations, which are enshrined in the provisions of IHL and IHRL instruments. The time span of occupation is also not expressly enshrined in the provisions of international law. However, it is presumed that occupations are temporary in nature.

While during temporary control, the occupying powers are required to facilitate the occupied people in relation to protection of their rights. If the occupying powers commit serious violations of the rights of the people during occupation, the other body of law known as International Criminal Law (ICL) will come into action (Azarova, 2017). Therefore, the express definition of the term occupation is missing in the provisions of the international law but the criteria of effective control must take place for application of ILOC and other bodies of international law. In terms of belligerent occupation, same provisions of the international law (LOC, IHL and IHRL) continue to apply.

\section{The term belligerent prolonged occupation}

Before examining the term "belligerent prolonged occupation", it is necessary to define the term "belligerent occupation" with linkage to the term "occupation". The word Belligerent means aggressive or confrontational. The territories are occupied by way of force or weapon thus aggression and confrontation are involved therein. The relevant provision of the international law on this point is article 42 of the Hague Regulations of 1907, which states that: 
"Territory is considered occupied when it is actually placed under the authority of the hostile army. The occupation extends only to the territory where such authority has been established and can be exercised."

It is a simple definition of the belligerent occupation. It implies that first, actual effective control must be exercised by the occupying power in occupied territory and second, the provisions of ILOC apply when the authority is established by the occupying power. The circumstances of the occupation vary from case to case and it may be analysed keeping in view the circumstances for triggering the definition. However, firm control and invasion or authority must be established by the occupying power (Field Manual, 1956). The occupation continues irrespective of resistance made by the other party. For occupation, the resistance is not necessary requirement under Hague Regulations of 1907. The effective control and established authority matters a lot for occupation as envisaged in article 42 of Hague Regulations, 1907.

Here one question arises which needs to be answered that what if aerial bombing or attack from sea takes place by the invader. Will it be considered as an occupation? The answer is no because firm control and authority have not been established by the invader or occupier. However, if an occupier or invader controlled the territory without resistance, then it may be called as occupation (Von Glahn, 1957). Thus, the criteria for a belligerent occupation are the same as in the case of occupation. On the other hand, the term belligerent prolonged occupation may be explained as stretched, protracted or lingering occupation. In other words, it simply means extended occupation by the occupier. Based on the Hague Regulations, the nature of occupation is temporary; thus, prolonged occupation is not allowed and inconsistent with the Hague Regulations. However, the same rules of ILOC, IHL and IHRL apply in prolonged occupation and the occupier is required to apply them with more strict care and attention because prolonged occupation is more sensitive case.

\subsection{Illegitimate and unauthorized prolonged occupation}

It is necessary to mention that the prolonged occupation is prohibited under the international law because if one allows it, it may amount to serious violation of the basic rights of the occupied people. The prolonged occupation is not expressly defined in terms of the international law, but it is a descriptive term to be used. International law prohibits illegal or unlawful acts to be committed by states, non-state actors and even individuals. It condemns all acts, which are in violation of human respect and dignity. It is designed to protect the rights of the people worldwide.

If an occupier transforms territory, annexes area, controls government or geographical characteristics of territory, it may amount to be illegal occupation under international law. If prolonged occupation is carried out by the occupying state in occupied territory, it may amount to violation of the Jus Cogens and basic human rights, which are available to everyone worldwide. The alteration of territory and violation of the basic human rights is strictly prohibited under international law. Occupation on territory on the basis of security is even temporary and the occupier is required to vacate or depart if a situation changes and becomes peaceful in such territory. Further, under international law, the occupying powers are obliged to take all necessary measures and steps to protect rights of the occupied population and to depart if circumstances so require. In temporary period, hostilities and sporadic violence is also prohibited (Lemkin, 2008). The rights of the population cannot be denied at any level. For 
Prolonged occupation: An analysis of obligations of the occupying powers in an occupied ...

instance, Field Manual (1956) states that "The number of troops necessary to maintain effective occupation will depend on various considerations such as the disposition of the inhabitants, the number and density of the population, the nature of the terrain, and similar factors". Given the definitions of occupation and prolonged occupation, the legal framework governing occupations is analysed in the upcoming section.

\section{International legal framework}

\subsection{Historical background/reflections}

Taking into consideration the case of belligerent occupation and by analysing the historical roots, two important documents are considered as basis for law of Belligerent occupation. These are; first, Hague Convention IV "respecting the laws and customs of war on land" of $18^{\text {th }}$ October, (1907) (HRIV) and second, Geneva Convention Relative to the Protection of Civilian Persons in Time of War of $12^{\text {th }}$ August, (1949)(GCIV). It may be classified as Hague and Geneva Law, respectively. The Hague law is general in nature and indicates the rules pertaining to belligerent occupation. It also provides rules for finance, government, property and administration. On the other hand, the Geneva law supplements it and provides detailed rules in relation to treatment and protection of Civilians. It is a supplementary document and is ratified by most of the states. The evolution of occupation laws started from debate of legal arena and customs. It is important to mention few stances whereby the concept of occupation was evolved along with annexation. The term evolved during $18^{\text {th }}$ century and debate continued when Napoleonic Wars took place. Russia also has taken oath of allegiance from Swedish citizens in 1809 (Von Glahn, 1957). The concept of occupation was recognized then because it was marked with control on foreign territory (Graber, 1949).

However, it also has created problems for international community to think about rules of Land warfare. No concrete legislation was available in relation to land warfare and occupation laws in particular except Hague Regulations and Geneva Conventions. The concept of annexation of territory was evolved. The term military occupation was used by Chief Justice John Marshall in 1828 where he stated that annexation is permanent act but for short time occupation rests (Benvenisti, 1993). He stated "the usage of the world is, if a nation be not entirely subdued, to consider the holding of conquered territory as mere military occupation, until its fate shall be determined at the treaty of peace" in American Insurance Company v. Canter, 1828.

In pursuit of Judgments laid down, the US has passed Army Manual, Instructions for the Government of Armies of the United States in the Field, in 1863, which laid basis for military occupation. It was very famous and commonly known as Lieber code (Von Glahn, 1957). The Code has described in detail rules concerning military occupation. It also has open ways for assessing the concepts of occupation and land warfare by other military forces and International community. The rules of the Lieber Code are followed in the European Brussels Declaration of 1874 and the Oxford Manual of 1880. These two documents elaborated further the concept of occupation and land warfare in order to develop international consensus on the subject. Although it was a difficult task to formulate detailed rules and regulations governing occupation and warfare but such like documents paved way for flourishing of the provisions of international law. While taking into consideration the experiences and with the passage of time, states have tried to formulate detailed rules on it. Resultantly, The Hague Conventions of 1899 and 1907 elaborated in detail the concept of occupation. However, the provisions have 
certain challenges but remained applicable during World War-I and World War-II, respectively. The provisions are applicable even to date (Von Glahn, 1957).

Looking into atrocities and violations of the rights during World War-II, states have decided to formulate detailed rules and ensure their implementation in 1949 after the inception of the UN. Many new concepts were introduced in a technical language. As a result, these issues are addressed by Geneva Conventions of 1949 in a detailed manner and in conjunction with Hague Regulations. Along with Hague and Geneva law, the law of belligerent occupation also entails force of customary international law. That is why; today we have Hague law and Geneva law in general which regulates the land warfare and occupation. However, ILOC is not confined to treaty sources alone. The other sources include Protocol I Additional to the Geneva Conventions of 12 August 1949 and relating to the Protection of Victims of International Armed Conflicts (AP-I), the UN resolutions and Customary International Law (CIL).

\subsection{The UN charter and ILOC}

Since the inception of the UN Charter, illegal invasion/occupation or use of force is prohibited expressly. However, violations of the Charter have been made on various instances by states. Territory has been occupied without approval from the UN in many cases. For instance, first; the islands of Northern Cyprus were occupied by Turkey; second, Israel has occupied the territory of Palestine; third Vietnam has occupied Cambodia; fourth, the occupation of East Pakistan and State of Jammu and Kashmir by India and lastly, Argentina has occupied Falkland Islands (Benvenisti, 1993). These cases are prominent examples of occupation and even few is continuing to date. These may be examples of prolonged occupation as well. However, legal title of an occupied territory cannot be acquired by the occupying power in any case. The occupying powers may only administer that territory until end of occupation. Under the UN Charter, occupation is allowed if the UNSC endorses the occupation or if the occupying power acknowledges the status of the territory (The UNSC Resolutions, 2003).

\section{Identifying sources of ILOC}

As mentioned earlier, the norms of ILOC are mentioned in Geneva law and Hague law. However, the treaties are the principal and main sources of ILOC. The provisions of these treaties apply directly to the occupying powers. For example, the provisions of Geneva Convention IV of 1949, which elaborates in detail rights of the civilians during occupation. Second, along with treaties other sources are also applicable. These sources include the UN Resolutions, Customary norms and domestic law of the occupier and occupied states. These sources will be analysed one by one in the paragraphs below.

\subsection{Analysis of the sources of ILOC}

\subsubsection{Treaties concerning occupation}

The main treaties of the occupation are the Hague Regulations of 1907, the fourth Geneva Convention of 1949, Additional Protocol I of 1977 (Roberts, 1984). All these treaties may be combinable and elaborate rights and duties of the occupying powers and occupied people. These also elaborate the "Protected persons" under international law. As far as Hague Regulations are concerned, these have binding force and binding on states under customary 
Prolonged occupation: An analysis of obligations of the occupying powers in an occupied ...

international law. The rules of GC-IV of 1949 are directly applicable on states. Its supplement, AP-I also elaborates rights and duties of the occupying powers. AP-I is additional to the Geneva Conventions and is binding on states. In short, the provisions of these three instruments collectively applicable during occupations and to protected persons.

\subsubsection{The Hague Regulations of 1899 and 1907}

There were disagreements among the States during the drafting of 1899 and 1907 Regulations. However, general rules are agreed upon by states (Nurick \& Barrett, 1946). As far as treaty law is concerned, The Hague Regulations of 1907 are considered as primary source of ILOC. Under Hague Regulations, chapter one addresses "The Qualifications of Belligerents." Article 1 provides that, "the laws, rights, and duties of war apply not only to armies, but also to militia and volunteer corps..." (Hague Regulations, 1907, art. 1). It extends the scope of the application of the article meaning that it is not limited to armed forces but also to private forces and unpaid assistants. It covers the occupying forces and forces of occupied people as well. Belligerents include all parties to the conflict. Article 2 addresses respect for all laws and stipulate that parties are required to "...carry arms openly and respect the laws and customs of war". In other words, it means that necessary force may be used and IHL and customary law must be observed during war.

The Hague regulations have also provided definition of the occupation and it is followed by states as envisaged in article 43. It also covers rights and duties of the occupying powers and occupied population. The rights and duties are binding because the Hague Regulations are part of CIL (Hague Regulations, 1907, arts. 43-56). All parties are required to follow these rules in letter and spirit. Though these Regulations are drafted for saving humanity, history reveals that gross violation of these Regulations has arisen in World War-I and World War-II, respectively. Such gaps or loopholes were covered by Geneva Conventions of 1949. These Conventions were meant to supplement the Hague Regulations but because of their detailed elaboration such conventions have repealed and replaced certain provisions and articles of Hague Regulations. However, in general, these conventions are treated as supplementary to the Hague Regulations of 1899 and 1907.

\subsubsection{The Geneva Conventions of 1949}

The Geneva Conventions of 1949 binds all states under customary international law (Roberts \& Guellf, 2000). These conventions elaborate the rules of IHL in detail. These are also supplemented by protocols later. These conventions cover the areas of occupation as well. These elaborate the obligations of the occupiers and are additional to the occupation laws (Roberts, 1984). These four Geneva Conventions of 1949 cover the rules of law during war. It is interesting to note that all of the four Geneva Conventions are directly applicable to the parties in the conflict, but their nature and subjects are different. For instance, Geneva Convention-I relates to wounded and sick at the battlefield whereas GC-II covers obligations of parties to a conflict and rights of wounded and sick at sea. Geneva Convention-III concerns with prisoners of war and fourth Convention relates to Civilians.

The purpose is to save humanity and treatment of protected persons is ensured by states under GC-IV. In terms of Occupation, Part II of GC-IV addresses that the occupying powers are under certain obligations in occupied territory. Further, it also addresses obligations of 
belligerents in relation to treatment of civilians and protected persons under articles 43-56 of GC-IV. Later in 1977, these Conventions are supplemented by two protocols. In 2005, third protocol was adapted which relates to the use of emblems. Though AP-I is designed to regulate International armed conflicts (IAC) but in terms of occupation, certain provisions relevant.

\subsubsection{Additional Protocol-I (AP-I) to the Geneva Conventions}

The aim of this protocol is to protect civilians during international armed conflict (IAC). It was designed to regulate IACs under which acts of guerrillas and explosion of liberation movements is covered (Roberts \& Guelff, 2000). The protocol is directly applicable to occupied territories; however, still it has certain challenges. For example, there is lack of enforcement mechanisms of these provisions in the situation of occupation. Certain deficiencies of ILOC are not completely covered by AP-I. However, it extends ILOC to "territories with a controversial international status" (Roberts, 1984). Under art. 75 of AP-I, parties to the conflict and the occupying powers are required to protect civilians and ensure basic protections.

\subsection{Overview of other instruments which are relevant to occupation}

Along with Regulations and treaties, several instruments of the UN are also considered as albeit non-binding source which is applicable in the case of occupation. For instance, The UN Basic Principles on the Use of Force and Firearms by Law Enforcement Officials is instructive in the context of an occupier's duty to restore and maintain public order. Article 4 provides that, "law enforcement officials, in carrying out their duty, shall, as far as possible, apply non-violent means before resorting to the use of force and firearms. They may use force and firearms only if other means remain ineffective...". It prohibits unnecessary use of force and requires enforcement officials to protect life of the individuals in all circumstances. However, these instruments are non-binding but the occupier's should observe them during occupation. In line with this discussion, another instrument is the International Covenant on Civil and Political Rights (ICCPR). It is Covenant signed by majority of the UN members and creates specific obligations on states in order to protect civil and political rights of the people. Under article 2 of the ICCPR, "no one shall be arbitrarily deprived of his life". It means the occupier's cannot take the life of the occupied people away in arbitrary manner. Only necessary use of force can be used in order to avoid violence and resistance. These two documents are important to taken into consideration by the occupying forces in an occupied territory. The non-binding documents may also be followed such as, the provisions of the UDHR, (1948) because it has moral force and is part of customary international law.

Along with the UN instruments, the UNSC Resolutions relevant to occupation are also important for consideration. For instance, the UNSC Resolution 1483, has contributed to the field of international law and particularly in an occupation. It's main features (as noted down by Benvenisti) include first occupation as a temporary and legal act. Second, sovereignty do not vest with occupier even after taking overall control in occupied territory. Third, the provisions of IHRL remain applicable during occupations and fourth, it poses duties on the occupier's to protect occupied people (Benvenisti, 2003). It raised certain questions that Do Resolutions of SC have primacy over treaty obligations or how inconsistency be removed, if it occurs between SC Resolution and the provision of the treaty? The UN Charter itself addresses it. The answer to this question is elaborated in article 103 of the UN Charter under which SC Resolutions have precedence. It is also important to note that the ICJ in Lockerbie Bombing 
Prolonged occupation: An analysis of obligations of the occupying powers in an occupied ...

Case also affirms this position, under which the Court by referring article 103 of the UN Charter held that the SC Resolutions have supremacy over treaty obligations in case of conflict.

\subsection{Customary International Law (CIL)}

States as well as the occupiers are bound by their rules, doctrines and domestic laws to follow customary international law in letter and spirit. For instance, US military forces are required to meet the terms of customary international law under domestic military manual. In terms of assessing customary nature of Geneva Conventions of 1949, the international criminal tribunal for Yugoslavia (ICTY) in 1995 held that these conventions are part of customary International law and binding on states even during an occupation. However, all Hague Regulations are not part thereof, but it does not mean that such Regulations can be completely ignored during occupation. Such Regulations serve as the basis of ILOC, which is later supplemented by Geneva Conventions. It was also reaffirmed by the Trial Chamber in 1997 that these conventions are part of CIL. Even certain provisions of the Geneva Conventions are Jus Cogens and non-derogable, for instance, prohibition on slavery, torture, discrimination etc. Along with the Geneva Conventions, certain articles of the AP-I of 1977 are also part of CIL and create obligations. However, few articles are contentious yet. Even the US has recognized certain articles of AP-I as customary law (Sofaer, 1988).

The significance of customary law is noted down in Prosecutor Vs Dusto Tadic, commonly Tadic Case, 1997 which is remarkable judgment of the Trial Chamber. The Chamber held that customary law is applicable in the case of occupation. The chamber has recognized entitlements of civilians in an occupied territory and held that they must be treated in humane manner. However, if they carry open arms or separate insignia, they may be targeted on grounds of necessity but humanely. Thus, the sources of ILOC include Treaties, Hague Regulations, the UN instruments, SC Resolutions and customary international law. It is necessary to identify obligations of the occupying powers during occupations therefore; it is analysed in the next section. It is important to note that 149 substantive articles of GCIV protect rights of the people in occupied territory. The abuse of these provisions is prohibited under international law, such as, IHL, IHRL, ILOC and ICL. The violations amount to war crimes. In this regard, the occupying forces are under obligations to respect and protect rights of the occupied. The obligations of occupier's during prolonged occupation are discussed in next section.

\section{The occupier's obligations during prolonged occupation}

The occupying powers are under general as well as specific obligations to respect, protect and fulfil rights of the occupied people during prolonged occupation. The obligations of the occupying powers during prolonged occupation can be classified into six broad headings with including subheadings namely, (i) Restoration of security for fulfilment of other obligations; (ii) Restoration of public order and law (art. 42 of Hague Regulations, 1907); (iii) Restoration and management of health by providing medical facilities and supplies (arts. 55-56 of GCIV, 1949); (iv) Deep care and attention of women and children's rights (art. 50 of GCIV, 1949); (v) Management of public and private property of occupied (arts. 23 and 52 of Hague Regulations, 1907); and (vi) facilitation and humane treatment of the occupied people in all respects (articles 27-54 of GCIV, 1949). These obligations are general in nature and must be respected by the occupying powers. Along with these obligations, the occupier and occupied both have other obligations and duties. 


\subsection{Restoration of security in occupied territory}

Security of the occupier and occupied are important in occupied territory. Once the security is restored or rebuild by the occupying power, the other obligations may also be fulfilled. It is also primary objective of occupier. For maintaining and restoration of security, the International Committee of the Red Cross (ICRC) states, "achieving security must be in conformity with international human rights law standards. These standards apply to all those acting under the US authority including members of the US and coalition armed forces Iraqi Police and international law enforcement officers" (Report Human Rights Watch, 2003).

\subsection{Restoration of law and order}

The fundamental and foremost obligation of the occupying power is to maintain and restore public order and law. It is incumbent on the occupier to "take all measures in his power to restore and ensure as far as possible public order and safety while respecting the laws in force in the country". It is important to note that the criteria of "effective control" must be fulfilled by the occupying power in occupied territory. Once "effective control" by the occupier is established, this obligation comes into play. It is recognized under customary and treaty law (Kelly, 1999). The establishment of effective control is difficult to identify in occupied territory. The determination of effective control depends on the actual authority of the occupier. However, the ICRC states, "there is no intermediate period between what might be termed the invasion phase and the inauguration of a stable regime of occupation. Even a patrol which penetrates into enemy territory without any intention of staying there must respect the Conventions in its dealings with the civilians it meets". In this context the report of Human Rights Watch (HRW) is also relevant which states, "under customary international law, this duty begins once a stable regime of occupation has been established, but under the Geneva Conventions, the duty attaches as soon as the occupying force has any relation with the civilians of that territory, that is, at the soonest possible moment, a principle that finds reflection in the US military policy" (Human Rights Watch Brief, 2003).

\subsection{Restoration and management of health}

The occupiers have also obligations in respect of protection of health rights of the occupied. The right to health must be protected in occupied territory including detainees (art. 56 of GCIV, 1949). These obligations also require implementing measures, which are preventive in nature. These include (a) combat the spread of contagious diseases and epidemics; and (b) ensure and maintain the cooperation of national and local medical and hospital establishments and services, and public health and hygiene in the occupied territory". The principal obligation lies on occupiers to meet and consider the basic needs of the occupied. The GCIV specifically states that the occupying powers are required to (a) ensure the food and medical supplies of the population; (b) agree to relief schemes; and (c) allow free passage of consignments of food, medical supplies and clothing.

\subsection{Deep care for vulnerable classes of society}

During the occupations, special concentration is given to the vulnerable classes of the society, such as, women and children. Along with general duties, the occupying powers have specific obligations too to protect basic rights of the women. Under international law, special protection 
Prolonged occupation: An analysis of obligations of the occupying powers in an occupied ...

is given to the women during occupations under which they are protected against "any attack to their honour in general and from rape, enforced prostitution or any form of indecent assault in particular". Along with women, the occupying forces are also required to protect rights of the individuals. The CRC and other human rights instruments pose obligations in this respect. The participation of children in armed conflict is prohibited. The occupying powers are in all circumstances required to protect the basic human rights of the children, such as, education, health etc.

\subsection{Restoration and management of property}

While after restoration of law and order and security, along with respecting lives of the people, the occupiers are required to respect property rights of the occupied people in occupied territory. This obligation requires respect for public as well as private property. The occupiers are prohibited to confiscate or impound the private property of the individuals. The general rule is that property cannot be taken away and rights of the occupied must be respected and protected by the occupier. However, for the purpose of security and maintaining rule of law, the public property may be used during occupation but for limited time period. The purpose of taking property must be genuine. In this context, the occupying powers are allowed to use public property and seize the property of the individuals, for instance, weapons, vessels, supplies and transport for military purposes. The time period for taking property of the individuals is limited and the occupying powers are required to restore property and fix damages or compensation if any when situation becomes normal or "when peace is made".

In line with criminal sanctions, the occupying powers are allowed to punish those who snip away property of the individuals. Even if the person or soldiers from the occupying force do so, the occupying force is allowed to punish accordingly. All forms of pillage or bootie are prohibited. Public assets must be respected and protected by the occupier in occupied territory. The administration and management of the public assets is necessity because they are trustees and not the owners of the property. They are required to "safeguard the capital of these properties", in all cases. Destruction of the property merely on the ground of security or maintain public order is strictly prohibited. During occupations, the occupying powers are required to protect all properties and not vice versa. The alteration or damage to the property is also forbidden. Along with respect for the public and private property, the occupying powers are required to respect religious, cultural property and other belongings of individuals in occupied territory. It is envisaged in Hague Regulations, which states, "the property of municipalities, institutions dedicated to religion, charity and education, the arts and sciences, even when State property, shall be treated as private property. All seizure of, destruction or wilful damage done to institutions of this character, historic monuments, works of art and science, is forbidden, and should be made the subject of legal proceedings".

\subsection{Facilitation and humane treatment of the occupied}

The protection of basic human rights is recognized worldwide under the provisions of IHRL. Even the obligations posed by IHRL are binding whether or not the occupying powers ratify human rights instruments. It is because of the protections given and nature of these provisions having force of CIL. However, under IHL such protections are also mentioned, and the occupiers are duty bound to respect basic human rights of the occupied people. During occupation, treatment of the occupied must be humane and to that end the occupying powers 
are required to treat in humane manner. The civilians, combatants as well as detainees have rights. For instance, the detainees are required not to be tortured or subject to physical or moral coercion in any case for obtaining information by the occupier. All forms of torture, disfigurement, mutilation, and physical punishment are also prohibited (art. 33 of GCIV).

The protected persons cannot be exterminated or subject to imposition of physical suffering or harassment (art. 32 of GCIV). Such conduct is not all allowed and illegal. The occupiers are required to abide by the provisions of law in this regard. The unlawful transfer, human trafficking and deportation are also prohibited (art. 33 of GCIV). Therefore, the treatment and facilitation to the occupied people is required by the occupying powers. These are general as well as specific obligations. The other obligations include entitlement of humane treatment even to detainees, prohibition on confinement "except when indispensable for safety and only while those circumstances continue to exist", protection of basic rights of accused violating laws of IHL, and guarantee of fair trial and counsel. In this regard, sentence is allowed only after fair trial and by Courts.

\section{Contemporary challenges}

The lack of express definition of occupation needs to be formulated in line with contemporary and growing challenges. However, article 42 of The Hague Regulations of 1907 defines occupation as, "territory is considered occupied when it is actually placed under the authority of the hostile army. The occupation extends only to the territory where such authority has been established and can be exercised". It means that there is requirement of establishing effective control in absence of sovereign title. The occupier under ILOC cannot acquire sovereignty. States and occupiers are required to respect existing laws. The presumption is that the nature of occupation is temporary and if prolonged, states have following challenges:

- Preservation of status quo by the occupier after end of occupation in letter and spirit

- Determination of beginning or end of occupation

- Control on misuse or abuse of the power conferred to the occupying power.

- System of check and balance for Gross human rights violations in occupied territory

- Protection of interests and welfare of the occupied and safeguarding their rights.

- Defining time span of the occupation.

- Removing long nature of occupation.

- Transformations made by the occupying powers in occupied territory.

- Check and balance for use of force.

- Protection and preservation of right to self-determination.

- Formulation of policy for armed non-state actors.

- Acts of violence and resistance.

- Acts of aggression and terrorism.

- Implementation and enforcement of international norms, like IHL, IHRL, and ILOC.

\section{Conclusion}

From the above discussion, it is concluded that the ILOC has evolved with a slow process and in $19^{\text {th }}$ century. The concepts regarding sovereignty and war changed because of the changing nature of war between states. After World War-II the Geneva Conventions were drafted to 
Prolonged occupation: An analysis of obligations of the occupying powers in an occupied ...

regulate armed conflicts. These replaced few articles of the Hague Regulations of 1899 and 1907. However, still there is need of further improvement by taking into account their implementation in letter and spirit. The paper has revealed that although the term occupation is defined under Hague Regulations, but it needs further elaboration. The term Belligerent occupation was introduced throughout $19^{\text {th }}$ century and various understandings of this term arose. The presumption regarding occupations is that occupations are temporary in general. In this context, the term belligerent prolonged occupation is also introduced in writings of legal arena, which caused confusions. However, it is not expressly defined under international law.

The definition of the occupation is extended to the term belligerent prolonged occupation. The sources of prolonged occupation are same as ordinary occupations. The legal framework for prolonged occupation is regulated by IHL, ILOC and IHRL. There exists complementarity in these bodies of law during occupation. However, the prolonged nature of occupation has severe and harsh legal consequences. It affects economic stability as well as the growth in occupied territory. It is argued that such effects of prolonged occupation may be condemned and possibly removed for the purpose of achieving peace and maintaining security worldwide. The evil of prolonged occupation can be removed by humanitarian involvement of international community. In this regard, the provisions of IHRL may be extended and applied strictly in occupied territories.

The paper has established that the occupiers or occupants are under international legal obligations to respect and promote rights of the occupied people. The legal framework is regulated by the bulk of ILOC, IHL and IHRL. These obligations include humane treatment of occupied in all situations; restoration of public law and order; management of public and private property; protection of health, education, women and children rights and facilitation in every respect. Given the severe nature of prolonged occupation and its consequences states as well as international community have certain challenges, such as, clarity of the determination or end of occupation; removal of the prolonged occupation; maintain security; aggression; terrorism and so on. These challenges need to be addressed by the international community. The prolonged nature of occupation must be removed in all aspects for protection of rights of the concerned people. The violation of the provisions of international law must be avoided by the occupying powers.

\section{References}

American Insurance Company v. Canter, 26 U.S. 511, 1828.

Azarova, V. (2017). Israel's unlawfully prolonged occupation: Consequences under an integrated legal framework. European Council on Foreign Relations.

Benvenisti, E. (2008). The origins of the concept of belligerent occupation. Law and History Review, 26(3), 621-648. https://doi.org/10.1017/S0738248000002595

Benvenisti, E. (1993). The International law of occupation. Princeton University.

Benvenisti, E. (2003). Water conflicts during the occupation of Iraq. The American Journal of International Law, 97(4), 860-872. https://doi.org/10.2307/3133685

Bhuta, N. (2005). The antinomies of transformative occupation. European Journal of International Law, 16(4), 721-740. https://doi.org/10.1093/ejil/chi145

Convention for the amelioration of the condition of the wounded and sick in armed forces in the field, 1949. https://www.refworld.org/docid/3ae6b3694.html 
Convention for the amelioration of the condition of wounded, sick and shipwrecked members of armed forces at sea, 1949. https://www.icj.org/wp-content/uploads/2014/06/GC-IIEN.pdf

Convention relative to the treatment of prisoners of war, 12 August 1949. https://www.refworld.org/docid/3ae6b36c8.html

Convention relative to the protection of civilian persons in time of war, 1949. https://www.un.org/en/genocideprevention/documents/atrocity-crimes/Doc.33_GCIV-EN.pdf

Fleming v. Page, 50 U.S. 603, 612, 13 276, 1850.

Graber, D. A. (1949). The development of the law of belligerent occupation, 1863-1914: A historical survey. Columbia University.

Guelff, R., \& Roberts, A. (Eds.). (2000). Documents on the laws of war. Oxford University.

Human Rights Watch briefing paper. (2003). International Humanitarian Law issues in a potential war in Iraq. http://www.hrw.org/backgrounder/arms/iraq0202003.htm

International covenant on civil and political rights, 1966.

Kelly, M. J. (1999). Restoring and maintaining order in complex peace operations: The search for a legal framework. Martinus Nijhoff Publishers.

Lemkin, R. (2008). Axis rule in occupied Europe: Laws of occupation, analysis of government, proposals for redress. The Lawbook Exchange Limited.

Lieber Code. (1863). The instructions for the government of armies of the United States in the field. General Order No: 100. https://avalon.law.yale.edu/19th_century/lieber.asp

Manual F. (1956). The law of land warfare. Field Manual No. 27-10, Department of the Army. Washington. http://www.combatindex.com/store/field_man/sample/fm_27-10.pdf

Nurick, L., \& Barrett, R. W. (1946). Legality of Guerrilla forces under the laws of war. American Journal of International Law, 40(3), 563-583. https://doi.org/10.2307/2193930

Opinion and judgement of trial chamber II of 17 May 1997. The prosecutor of the tribunal against Dusko Tadic, Case No. It-94-1-I

Report of Human Rights Watch. (2003). The war in Iraq and International Humanitarian Law. https://www.hrw.org/legacy/campaigns/iraq/ihlfaq.pdf

Roberts, A. (1984). What is a military occupation? British Yearbook of International Law, 55(1), 249-305.

Sofaer, A. D. (1988). Agora: The US decision not to ratify protocol I to the Geneva Conventions on the Protection of War Victims (Cont'd). American Journal of International Law, 82(4), 784-787. https://doi.org/10.2307/2203512

The Hague Regulations, 1907.

The UN Security Council Resolution No: 1483, 2003.

United States v. Rice, 17 U.S. 4 Wheat. 246 (1819)

UN basic principles on the use of force and firearms by law enforcement officials. http://www.hri.ca/uninfo/treaties/43.shtml

$\begin{array}{lllll}\text { Vienna } & \text { Convention on the law of treaties, } 1969 .\end{array}$ https://legal.un.org/ilc/texts/instruments/english/conventions/1_1_1969.pdf

Von-Glahn, G. (1957). The occupation of enemy territory: a commentary on the law and practice of belligerent occupation. University of Minnesota. 